\title{
HYPOGLYCEMIC EFFECT OF HIGH-RESISTANT STARCH ANALOG RICE THROUGH GLP-1 AND INSULIN OR HIGH-RESISTANT STARCH ANALOG RICE ATTENUATES BLOOD GLUCOSE LEVEL THROUGH ENHANCEMENT OF GLP-1 AND INSULIN
}

\author{
HAIRRUDIN $^{1}$, SOETJIPTO ${ }^{2,3}$, RETNO HANDAJANI ${ }^{2,3 *}$ \\ ${ }^{1}$ Department of Biochemistry, Faculty of Medicine, University of Jember, Indonesia. ${ }^{2}$ Department of Medical Biochemistry, Faculty of \\ Medicine, Universitas Airlangga, Indonesia. ${ }^{3}$ Institute of Tropical Disease, Universitas Airlangga, Indonesia. Email: retno-h@fk.unair.ac.id
}

Received: 05 May 2019, Revised and Accepted: 24 June 2019

ABSTRACT

Objective: This study was to investigate the effect of analog rice (AR) on glucagon-like peptide-1 (GLP-1) and insulin serum levels, glucose transporter-2 (GLUT-2) expression, and fasting blood glucose (FBG) level in diabetic rats.

Methods: Fifty male Wistar rats divided into the control group $(n=10)$ and the experimental group. High-fat diet and streptozotocin were administered in experimental groups, which then divided into four equal groups ( $\mathrm{n}=10$, each) (negative control group, rice group, AR1 and AR2 group, given standard pellet, rice pellet, AR1 and AR2 pellet, respectively, for 6 weeks). GLP-1 and insulin serum levels were measured by enzyme-linked immunosorbent assay. The expression of GLUT-2 and the number of pancreatic $\beta$-cells observed using an immunohistochemistry method.

Results: FBG levels in the AR1 and AR2 groups decreased, while the rice group remained. GLP-1 serum levels of the negative control and rice groups were not significantly different from the control group, while the AR1 and AR2 groups higher than the control group (p $\leq 0.05$ ). All the treatment groups had insulin serum levels significantly lower than control group ( $\mathrm{p} \leq 0.05$ ), except the AR1 group. The expression of GLUT-2 and the number of pancreatic $\beta$-cells in the treatment groups were less than the control group, but between treatment groups were not significantly different.

Conclusion: AR significantly effective in reducing FBG level in diabetic rats through stimulation of increased GLP-1 and insulin serum levels serum levels but AR did not affect on the expression of GLUT-2.

Keywords: Analog rice, Resistant starch, Glucagon-like peptide-1, Insulin, Glucose transporter-2, $\beta$-cell.

(C) 2019 The Authors. Published by Innovare Academic Sciences Pvt Ltd. This is an open access article under the CC BY license (http://creativecommons. org/licenses/by/4. 0/) DOI: http://dx.doi.org/10.22159/ajpcr.2019.v12i8.33944

\section{INTRODUCTION}

Diabetes mellitus (DM) prevalence worldwide increased by $11 \%$ within 4years. In 2013, the number of diabetic patients was381.8 million [1] and increased to 425 million in 2017 [2,3]. It is estimated that DM patients in the world will reach 591.9 million in 2035 [1,2]. DM is a troubling disease because it causes many complications, both acute and chronic. Such complications include stroke, heart failure, kidney failure, sexual dysfunction, cataracts, and gangrene $[2,4]$.

DM management needs to integrate the drug therapy [5], diet [6,7], exercise $[7,8]$, and possible complementary treatments [9]. The successful management of DM is influenced by lifestyle [7,9], includes eating habits $[4,6,7]$. Most of the world's population has eating habits using easily absorbed foods, rich in carbohydrates, low in fiber, and resistant starch (RS), such as rice. DM patients who consume rice as a staple food can result in suboptimal control of blood glucose [10]. This can contribute to therapeutic failure of DM; therefore, we need to find a substitute staple food.

Analog rice (AR) can be considered as an alternative diet management for diabetic patients. AR is artificial rice which has adjustable composition according to the needs. It can contain high RS and highfiber ingredients. Former studies reported that high-fiber diet could improve blood glucose control and attenuate hyperinsulinemia in DM type 2 patients $[6,11]$. Therefore, this study was to analyze the mechanism of blood glucose improvement after AR consumption in diabetic rat model.

\section{METHODS}

Ethical clearance was obtained from the Animal Care and Use Committee Veterinary Faculty, Airlangga University, No. 667-KE/2017.

\section{Making rice pellets, $A R$, and $A R$ pellets}

Rice pellet was made by substituting $60 \%$ of carbohydrate content of standard pellet with rice (IR 64). AR was produced using hot extruder technology with twin screws [12]. The compositions are found in Table 1. There are two types of AR, each named AR 1 and AR 2. AR pellets were made by substituting $60 \%$ of carbohydrate content from standard pellets with each type of AR. All the pellets have the same calories (iso calories).

\section{Rat preparation}

A total of 55 rats Wistar strain, 3 months old, body weight 160-200 g, were randomly divided into control group $(\mathrm{n}=10)$ and experimental group $(\mathrm{n}=45)$. The control group was fed with standard feed formula for 3 weeks, whereas the experimental group was fed with high-fat diet (HFD) containing 23\% fat (lard fat) for 3 weeks and injected with streptozotocin (STZ) (BioWORLD) $35 \mathrm{mg} / \mathrm{kg}$ intraperitoneal at the end of the $2^{\text {nd }}$ week $\left(14^{\text {th }}\right.$ day). The STZ was dissolved in citrate buffer $(0.05$ $\mathrm{M}, \mathrm{pH} 4.5)[13,14]$. At the end of the 3th week of HFD administration $\left(21^{\text {th }}\right)$ or After 7 day of injection of STZ. FBG levels of all the rats were measured through the tip of the rats tail $[13,14]$, using glucometer (Easy Touch, Taiwan). The experimental group which had fasting blood glucose (FBG) levels between $300-450 \mathrm{mg} / \mathrm{dl}$ was randomly divided into four equal groups, each of 10 rats per group, namely: (1) Negative 
control group: Fed with standard pellets; (2) rice group: Fed with rice pellets; (3) AR1 group: Fed with AR1 pellets; and (4) AR2 group: Fed with AR2 pellets. Each pellet was given ad libitum for 6 weeks. At the end of the $6^{\text {th }}$ week, after being pellets provisioning, the rats were fasted for $8 \mathrm{~h}$ then measured blood glucose level using glucometer. Moreover, the rats were terminate; then, the blood and pancreas were taken for the measurement of research parameters.

\section{Research parameters measurement}

FBG levels were measured from 8-h fasting rats using glucometer. Glucagon-like peptide-1 (GLP-1) serum levels were measured by the enzyme-linked immunosorbent assay (ELISA) method using rat GLP1 ELISA assay kit (produced by Novateinbio). Data were expressed as $\mathrm{ng} / \mathrm{ml}$. Insulin serum levels were measured by the ELISA method, using rat insulin ELISA assay kit (produced by Novateinbio). Data were expressed as $\mu \mathrm{IU} / \mathrm{ml}$. Immunohistochemistry analysis of the expression of glucose transporter-2 (GLUT-2) and the number of pancreatic $\beta$-cells used single-stain monoclonal antibody. Expression of GLUT-2 was calculated from cell that contains GLUT-2 bonds with GLUT-2 monoclonal antibodies. Pancreatic $\beta$-cells with purple color were scored for the presence of GLUT-2 with brown color. It was quantitatively measured by counting on 10 selected high-power fields $(\times 400)$ using light microscope.

\section{RESULTS}

Rice (original rice) does not contain RS. Meanwhile, AR1 and AR2, each has $16.83 \%$ and $11.46 \%$ RS (Table 2). AR has 4 times higher in fiber content than original rice. Among them, AR1 has the highest fiber which is $1.77 \%$.

\section{FBG level}

There was no difference in pre-induction the FBG level between groups. Post-induction FBG level of the control group did not change, whereas post-induction FBG level of the experimental groups has increased, but there was no significant difference on FBG levels between the experimental groups. After 6 weeks of diet therapy, the FBG of control group was $94.95 \pm 0.51 \mathrm{mg} / \mathrm{dl}$. The FBG level in the control negative and rice groups did not differ significantly, while the AR1 and AR2 groups decreased significantly.

\section{The GLP-1 and insulin serum levels}

The mean of GLP-1 serum level of control group was $46.09 \pm 4.3 \mathrm{ng} / \mathrm{ml}$. The mean of GLP- 1 serum levels of negative control and rice groups did not differ significantly with control group $(\mathrm{p} \leq 0.05)$, while AR1 and AR2 groups increased significantly. The GLP-1 serum level AR1

Table 1: The composition of analog rice

\begin{tabular}{lcc}
\hline Ingredient & AR1 & AR2 \\
\hline Modified cassava flour & 16.2 & 32.4 \\
Rice flour & 21.6 & 5.4 \\
Cornstarch & 16.2 & 16.2 \\
Soy protein & 3.9 & 3.9 \\
Palm oil & 1.4 & 2.1 \\
Sodium alginate & 0.7 & 0.0 \\
Total & 60.0 & 60.0 \\
\hline
\end{tabular}

AR1: Analog rice 1, AR2: Analog rice 2, MOCAF produced by PT Bangkit Cassava Mandiri, Indonesia. Produced from fermented cassava and then made into flour [12]. All measured in g. MOCAF: Modified cassava flour

Table 2: Calorie, fiber, and RS content in $100 \mathrm{~g}$ analog rice

\begin{tabular}{llll}
\hline Description & Calorie (cal) & Fiber $(\mathbf{g})$ & RS $(\mathbf{g})$ \\
\hline Rice & 398.4 & 0.41 & 0,00 \\
AR1 & 382.7 & 1.77 & 16.83 \\
AR2 & 379.8 & 0.86 & 11.46 \\
\hline
\end{tabular}

RS: Resistant starch, AR1: Analog rice 1, AR2: Analog rice 2. Calorie was measured in calorie. Fiber and RS were measured in $\mathrm{g}$ group was higher than AR2 group but was not significantly. The mean insulin serum level in the control group was $136.21 \pm 17.4 \mu \mathrm{IU} / \mathrm{ml}$. All experimental groups had significantly lower serum insulin levels than the control group ( $\mathrm{p} \leq 0.05)$, except AR1 group. AR1 and AR2 groups had significantly higher serum insulin levels than rice group.

The expression of GLUT-2 and the number of pancreatic $\beta$-cells Observations on $\beta$-cells in the islets of Langerhans showed that experimental groups had pancreatic $\beta$-cells damaged so that the number of the cells less than the control group significantly. The diameter or the area islets of Langerhans of experimental groups was shorter or narrower than control group. Expression of GLUT-2 of pancreatic $\beta$-cells was not different significantly between experimental groups.

\section{DISCUSSION}

\section{The effects of AR on GLP-1 serum level in diabetic rats}

The GLP-1 serum level on negative control group and rice group was not different from the control group. This indicates that the administration of HFD and STZ did not affect in significant changes on GLP-1 serum level and the administration of rice for 6 weeks has not been shown to significantly increase GLP-1 serum levels. These results indicated that GLP-1 serum level in diabetes was normal and administration of rice did not increase GLP-1 serum level (Table 3).

The administration of AR for 6 weeks has been shown to increase GLP1 serum levels significantly. This effect occurs because AR has a high RS and fiber. Correlation test showed a significant relationship between GLP-1 serum level with RS (0.736) and fiber (0.733). RS and fiber inhibit the digestion and absorption of food in the intestine and accelerating the onset of satiety $[11,15,16]$. This effect leads to the stimulation of $\mathrm{L}$ cells in the intestine to secrete GLP-1 [17].

The RS [18,19] and fiber [10] cannot be digested; then, it will be fermented by the microbiota in the intestine [18-20] and generated short-chain fatty acid (SCFA) $[17,20]$. SCFA can stimulate intestinal L cells which result in an increase on GLP-1 secretion of the cells $[17,18]$. The results of another study showed that administration of an acute a fiber-rich diet had no effect on plasma levels of GLP-1 [21]. In this study, diabetic rats were given AR which rich in fiber for 6 weeks. The results showed different effects, fiber has a strong effect on increasing GLP-1 serum levels. This fact suggests that the provision of fiber has increasing effect on GLP-1 level if given repeatedly. The provision of fiber takes a long time to increase in GLP-1 serum level. AR1 is stronger than AR2 to increase GLP-1 serum levels due to higher levels of RS and fiber.

The effects of AR on the expression of GLUT-2 and the number of pancreatic $\beta$-cells

The results obtained in this study indicate that an increase in GLP-1 serum level in the AR1 and AR2 group was not followed by an increase in expression of GLUT-2 and number (total) of pancreatic $\beta$-cells (Table 4).

Table 4 shows that the amount of pancreatic beta-cells which expressing GLUT-2 in the experimental group did not differ significantly from the

Table 3: GLP-1 and insulin serum levels

\begin{tabular}{lll}
\hline Group & GLP-1 & Insulin \\
\hline Control & $46.09 \pm 04.3$ & $136.21 \pm 17.4$ \\
Negative control & $44.89 \pm 11.2$ & $90.12 \pm 20.8$ \\
Rice & $38.65 \pm 14.4$ & $82.65 \pm 16.6$ \\
AR1 & $84.29 \pm 20.9$ & $128.17 \pm 16.1$ \\
AR2 & $65.07 \pm 10.6$ & $112.53 \pm 23.7$ \\
\hline
\end{tabular}

$\mathrm{n}=10$, values are given as mean \pm SD, GLP-1: Glucagon-like peptide- 1 was measured in $\mathrm{ng} / \mathrm{ml}$, insulin was measured in $\mu \mathrm{IU} / \mathrm{ml}$, AR1: Analog rice 1 AR2: Analog rice 2. SD: Standard deviation 
control group. Since GLP-1 serum levels in the AR1 and AR2 groups increased, but GLUT-2 expression and the number of $\beta$-cells of pancreas were not different (not change) compared to the negative control group, we suspected that GLP-1 had no stimulating effect on GLUT-2 expression and pancreatic $\beta$-cell regeneration. The results of statistics analysis showed no association between GLP-1 with GLUT-2 expression and amount of $\beta$-cell of pancreas ( $>0.05$ ). The results of this study differ from the previous studies which stated that GLP-1 might stimulate GLUT2 expression, thereby increasing the sensitivity of pancreatic $\beta$-cells [21].

Immunohistochemistry analysis of the pancreas (Fig. 1) revealed that the diameter of the islets of Langerhans in all experimental groups was shorter than the control group. The number of pancreatic $\beta$-cells in the islets also decreased significantly (Table 4). This change occurs due to the administration of STZ which results in damage to $\beta$-cells of pancreas. After giving the AR for 6 weeks, there was no increasing diameter from the islets of Langerhans or the number of pancreatic $\beta$-cells. Therefore, it was taken together from the data a conclusion that giving AR does not provide stimulation for pancreatic $\beta$-cell regeneration.

\section{The effects of AR on insulin serum levels}

The number of pancreatic $\beta$-cells which decreased in the experimental group resulted in decreased insulin secretion so that insulin serum levels in the experimental groups were lower than the control group. In Table 3, it can be seen that insulin serum level in the negative control group is lower than the control group. Table 3 shows that giving rice diet for 6 weeks cannot increase insulin serum levels, otherwise giving AR for 6 weeks can increase insulin serum level in diabetic rats. That is because AR has higher levels of RS and fiber than rice, so AR can increase GLP-1 higher than rice. Furthermore, GLP-1 stimulates insulin secretion [15].
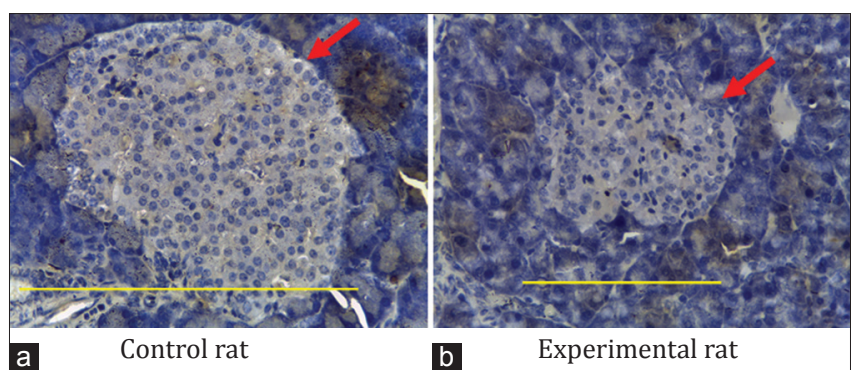

Fig. 1: Histology of the control rat pancreas (a), histology of the induced (diabetes mellitus) rat pancreas (b). The red arrows indicate the islets of Langerhans, the yellow line indicates the diameter the islets, IHC $\times 400$
There are several possible mechanisms that correlate the increase in serum GLP-1 with insulin serum level, namely: (1) pancreatic $\beta$-cell protective or prevention of apoptosis [22] and proliferation pancreatic $\beta$-cells [15] so that the number of the cells increases; (2) stimulating GLUT-2 expression $[23,24]$.

The facts obtained from this research showed no significant difference in the expression of GLUT- 2 and the number of pancreatic $\beta$-cells between groups although there were differences in GLP-1 serum levels. This proves that the stimulation effect on insulin secretion by GLP-1 was not through increased expression of GLUT-2 or an increase in the number of pancreatic $\beta$-cell. Hence, the effect of stimulation on insulin secretion by GLP-1 was likely through an increase in the number of receptors $[15,23]$ or through other mechanisms such as stimulation on hexokinase activity [23].

The assumption mechanism for increasing insulin secretion through increasing the number of these receptors according to with the alleged effects of GLP-1 on insulin secretion occurs through activation adenylyl cyclase. This activation resulted in increased cyclic adenosine monophosphate and protein kinase A activity. This condition results in increased levels of intracellular calcium resulting in an increase in exocytosis (secretion) of insulin [25]. Hence, the more receptors the more insulin secretions. The effect of AR1 in stimulating insulin secretion was stronger than AR2. Administration of AR1 can restore insulin serum levels which are almost the same as control group, while AR2 increases insulin serum levels but has not been able to return to normal levels.

\section{The effects of AR on FBG level in diabetic rats}

After getting diet therapy for 6 weeks, FBG level in the negative control and rice group has not differ significantly, whereas the AR1 and AR2 groups have decreased significantly (Table 5). The decrease in FBG in the AR1 and AR2 groups could be due to the effect of RS and fiber on AR. RS [19] and fiber [11] have the effect of inhibiting the digestion process because it can inhibit the activity of digestive enzymes, resulting in more controlled blood glucose levels. This statement is consistent with other studies that prove fiber plays a role in controlling blood glucose levels. These effects associated with barriers to digestion and absorption of carbohydrates [26].

RS [20] and fiber [11] in the large intestine will be fermented by microbiota and produce SCFA $[27,28]$. Furthermore, SCFA stimulates GLP-1 secretion, hereafter, GLP-1 stimulates insulin secretion. Increased insulin secretion results in a decrease in blood glucose levels.

SCFA also has the effect of inhibiting activity of hormone-sensitive lipase in the blood [28] so that there was a decrease in lipolysis; furthermore,

Table 4: The expression of GLUT-2 and the number of pancreatic $\beta$-cells

\begin{tabular}{llll}
\hline Group & $\boldsymbol{\beta}$-cells with expression of GLUT-2 & $\boldsymbol{\beta}$-cells without expression of GLUT-2 & Total $\beta$-cell \\
\hline Control & $11.65 \pm 5.1$ & $20.15 \pm 7.9$ & $31.80 \pm 7.3$ \\
Negative control & $8.45 \pm 2.7$ & $8.08 \pm 3.0$ & $16.53 \pm 5.6$ \\
Rice & $8.16 \pm 2.3$ & $10.76 \pm 5.1$ & $18.92 \pm 6.8$ \\
AR1 & $7.95 \pm 1.8$ & $9.50 \pm 2.5$ & $17.45 \pm 3.4$ \\
AR2 & $7.55 \pm 6.0$ & $10.44 \pm 3.7$ & $17.99 \pm 4.3$ \\
\hline
\end{tabular}

$\mathrm{n}=10$, values are given as mean \pm SD, GLUT-2: Glucose transporter-2, AR1: Analog rice 1, AR2: Analog rice 2. SD: Standard deviation

Table 5: Fasting blood glucose levels pre- and post-induction and post-therapy

\begin{tabular}{llll}
\hline Group & FBG & & \\
\cline { 2 - 4 } & Pre-induction & Post-induction & Post-therapy \\
\hline Control & $93.70 \pm 6.3$ & $96.25 \pm 04.5$ & $94.95 \pm 05.1$ \\
Negative control & $93.40 \pm 6.3$ & $367.75 \pm 23.6$ & $303.25 \pm 16.8$ \\
Rice & $94.30 \pm 7.6$ & $366.25 \pm 26.4$ & $378.00 \pm 13.2$ \\
AR1 & $93.50 \pm 6.4$ & $366.70 \pm 29.8$ & $125.05 \pm 12.1$ \\
AR2 & $93.95 \pm 6.6$ & $368.50 \pm 28.3$ & $152.00 \pm 25.4$ \\
\hline
\end{tabular}

$\mathrm{n}=10$, values are given as mean $\pm \mathrm{SD}$, FBG: Fasting blood glucose is measured in $\mathrm{mg} / \mathrm{dl}$, AR1: Analog rice 1, AR2: Analog rice 2. SD: Standard deviation 
the free fatty acid (FFA) will decrease. Decreasing levels of FFA in the blood will increase insulin sensitivity [28] and reduce resistance to hexokinase enzyme activity; thereby, glycolysis and glycogenesis will increase so that the blood glucose levels decrease [20,27,29]. Because AR1 and AR1 contain high RS and fiber, it will be absorbed more slowly. Foods that are slower in absorption will have a lower glycemic index so that AR1 and AR have the opportunity to be developed into a staple food for DM patients.

\section{CONCLUSION}

Based on these results, we concluded that AR significantly effective in reducing blood glucose level in diabetic rats through stimulation of increased GLP-1 and insulin serum levels but does not affect the expression of GLUT- 2 and the number of pancreatic $\beta$-cell. The highlight of this study was that AR1 showed a strong effect in reducing blood glucose levels so that it has the potential to be developed as a staple food substitute for DM patients.

\section{AUTHORS' CONTRIBUTIONS}

The topic of the research came from the first author. All the authors have the same contribution in carried out the research, determine the research method, collected and analyzed the data, and formatted these manuscripts.

\section{CONFLICTS OF INTEREST}

The authors declare that there are no potential conflicts of interest regarding the publication of this paper.

\section{REFERENCES}

1. Paneni F, Cosentino F. Diabetes and Cardiovascular Disease: A Guide to Clinical Management. Switzerland: Springer International Publishing; 2015.

2. International Diabetes Federation. Diabetes Atlas. $8^{\text {th }}$ ed. International Diabetes Federation; 2017. Available from: http://www. diabetesatlas.org

3. Cho NH, Shaw JE, Karuranga S, Huang Y, da Rocha Fernandes JD, Ohlrogge AW, et al. IDF diabetes atlas: Global estimates of diabetes prevalence for 2017 and projections for 2045. Diabetes Res Clin Pract 2018;138:271-81.

4. Jameson JL, Fauci AS, Kasper DL, Hauser SL, Longo DL, Loscalzo J. Harrison's Principles of Internal Medicine. $20^{\text {th }}$ ed. Newyork: Mc GrawHill's Education; 2018

5. Tjay TH, dan Rahardja K. Obat-Obat Penting: Khasiat, Penggunaan dan Efek Sampingmya. $7^{\text {th }}$ ed. Jakarta: Gramedia; 2015.

6. Ahola AJ, Forsblom C, Groop PH. Adherence to special diets and its association with meeting the nutrient recommendations in individuals with Type 1 diabetes. Acta Diabetol 2018;55:843-51.

7. Bhosale A, Thangavelu PD. Effect of lifestyle modification in Type II diabetes mellitus individuals. Asian J Pharm Clin Res 2019;12:381-3.

8. Codella R, Terruzzi I, Luzi L. Why should people with Type 1 diabetes exercise regularly? Acta Diabetol 2017;54:615-30.

9. Kalsi A, Singh S, Taneja N, Kukal S, Mani S. Current treatments for Type 2 diabetes, their side effects and possible complementary treatments. Int J Pharm Pharm Sci 2015;7:13-8.

10. Soong YY, Quek RY, Henry CJ. Glycemic potency of muffins made with wheat, rice, corn, oat and barley flours: A comparative study between in vivo and in vitro. Eur J Nutr 2015;54:1281-5.

11. Bendich A, Deckelbaum RJ. Preventive Nutrition: The Comphrehensip
Guide for Health Provesionals. $5^{\text {th }}$ ed. Switzerland: Humana Press; 2015.

12. Subagio A, Windrati WS. Pengaruh komposisi MOCAF (modified cassava flour) dan tepung beras pada karakteristik beras cerdas. Pangan 2012;21:29-38.

13. Srinivasan K, Viswanad B, Asrat L, Kaul CL, Ramarao P. Combination of high-fat diet-fed and low-dose streptozotocin-treated rat: A model for Type 2 diabetes and pharmacological screening. Pharmacol Res 2005;52:313-20.

14. Arumugam S, Natesan S. Hypoglycemic effects of Barleria noctiflora fractions on high fat fed with low dose streptozotocin induced Type 2 diabetes in rats. Int J Pharm Pharm Sci 2016;8:193-200.

15. Bhat GA, Khan HA, Alhomida AS, Sharma P, Singh R, Paray BA, et al. GLP-I secretion in healthy and diabetic wistar rats in response to aqueous extract of Momordica charantia. BMC Complement Altern Med 2018;18:162.

16. Fujii H, Iwase M, Ohkuma T, Ogata-Kaizu S, Ide H, Kikuchi Y, et al. Impact of dietary fiber intake on glycemic control, cardiovascular risk factors and chronic kidney disease in Japanese patients with Type 2 diabetes mellitus: The Fukuoka diabetes registry. Nutr J 2013;12:159.

17. Kassaian N, Feizi A, Aminorroaya A, Jafari P, Ebrahimi MT, Amini M, et al. The effects of probiotics and synbiotic supplementation on glucose and insulin metabolism in adults with prediabetes: A double-blind randomized clinical trial. Acta Diabetol 2018;55:1019-28.

18. Vidrine K, Ye J, Martin RJ, McCutcheon KL, Raggio AM, Pelkman C, et al. Resistant starch from high amylose maize (HAM-RS2) and dietary butyrate reduce abdominal fat by a different apparent mechanism. Obesity (Silver Spring) 2014;22:344-8.

19. Zaman SA, Sarbini SR. The potential of resistant starch as a prebiotic. Crit Rev Biotechnol 2016;36:578-84

20. Firdaus J, Sulistyaningsih E, Subagio E. Research article resistant starch modified cassava flour (MOCAF) improves insulin resistance. Asian J Clin Nutr 2018;10:32-6.

21. Bodinham CL, Al-Mana NM, Smith L, Robertson MD. Endogenous plasma glucagon-like peptide-1 following acute dietary fibre consumption. Br J Nutr 2013;110:1429-33.

22. Ravassa S, Zudaire A, Díez J. GLP-1 and cardioprotection: From bench to bedside. Cardiovasc Res 2012;94:316-23.

23. D'Alessio D, Lu W, Sun W, Zheng S, Yang Q, Seeley R, et al. Fasting and postprandial concentrations of GLP-1 in intestinal lymph and portal plasma: Evidence for selective release of GLP-1 in the lymph system. Am J Physiol Regul Integr Comp Physiol 2007;293:R2163-9.

24. Ravassa S, Zudaire A, Carr RD, Díez J. Antiapoptotic effects of in murine HL-1 cardiomyocytes. Am J Physiol Heart Circ Physiol 2011;300:H1361-72.

25. Lim S, Eckel RH. Pharmacological treatment and therapeutic perspectives of metabolic syndrome. Rev Endocr Metab Disord 2014; 15:329-41.

26. Brockman DA, Chen X, Gallaher DD. Hydroxypropyl methylcellulose, a viscous soluble fiber, reduces insulin resistance and decreases fatty liver in zucker diabetic fatty rats. Nutr Metab (Lond) 2012;9:100.

27. Deng J, Wu X, Bin S, Li TJ, Huang R, Liu Z, et al. Dietary amylose and amylopectin ratio and resistant starch content affects plasma glucose, lactic acid, hormone levels and protein synthesis in splanchnic tissues. J Anim Physiol Anim Nutr (Berl) 2010;94:220-6.

28. Maki KC, Pelkman CL, Finocchiaro ET, Kelley KM, Lawless $\mathrm{AL}$, Schild AL, et al. Resistant starch from high-amylose maize increases insulin sensitivity in overweight and obese men. J Nutr 2012;142:717-23.

29. Rodwell VW, Bender DA, Botham KM, Kennelly PJ, Weil PA. Harper's Illustrated Biochemistry. $30^{\text {th }}$ ed. New York: McGraw-Hill Education; 2015. 